\title{
- POPRAWA JAKOŚCI ŻYCIA OSÓB W PODESZZYM WIEKU POPRZEZ OPRACOWANIE BIZNESPLANU DOMU OPIEKI NAD OSOBAMI STARSZYMI
}

\author{
IMPROVING THE QUALITY OF LIFE IN OLDER PEOPLE THROUGH DEVELOPING THE BUSINESS \\ PLAN FOR THE ELDERLY CARE HOME
}

\author{
Daria Nowadzka \\ studentka zdrowia publicznego \\ Uniwersytet Medyczny im. Karola Marcinkowskiego w Poznaniu
}

DOI: https://doi.org/10.20883/pielpol.2017.43

\begin{abstract}
STRESZCZENIE
Celem artykułu jest przedstawienie biznesplanu domu opieki nad osobami starszymi, jako formy projekcji działalności gospodarczej, oraz weryfikacji opłacalności założonego przedsięwzięcia, mając na względzie poprawę jakości życia osób w podeszłym wieku.

Biznesplan składa się z najważniejszych informacji, które dotyczą danego projektu, oraz zawiera wszystkie kwestie związane z zakładaniem, rozwojem oraz zarządzaniem działalności. Biznesplan jest źródłem wiedzy o potencjale drzemiącym w projekcie działalności, a ponadto wskazuje szanse i zagrożenia, które wynikają z teraźniejszej oraz przyszłej sytuacji na rynku.

Biznesplan, który został opracowany dla domu opieki nad osobami starszymi „Spokojna Przystań”, ukazał wszystkie mocne i słabe strony tego przedsięwzięcia oraz jego szanse i zagrożenia. Wnikliwa analiza pozwoliła określić konkurencję na rynku oraz fakt istnienia zapotrzebowania na usługi świadczone przez taki zakład opieki, który umożliwi poprawę jakości życia osób w podeszłym wieku. Doskonała lokalizacja oraz rozwinięta oferta pozwolą firmie zaistnieć na rynku. Wyliczenia w planie finansowym wykazały, iż przedsięwzięcie może być opłacalne w przyszłości.
\end{abstract}

SŁOWA KLUCZOWE: biznesplan, dom opieki, jakość życia, osoby starsze.

\section{Wstęp}

Na całym świecie, w tym także w Polsce, obserwujemy starzenie się społeczeństwa. Ludzie w podeszłym wieku są bardzo cennym źródłem informacji o historii, ale niestety nie każdy ma możliwość cieszyć się obecnością takiej osoby wśród swoich bliskich. Niektórzy postrzegają seniorów jako ludzi, którym należy współczuć z powodu chorób czy ograniczenia ich sprawności. Jednak większość z nich wbrew pozorom cieszy się życiem i stara podążać za nowościami, troszcząc się jed-

\begin{abstract}
The paim of this article is to present the business plan for the elderly care home as a form of business projection and verification of the project feasibility with a view to improving quality of the elderly life.

The business plan consists of the most important information that is relevant to the project and includes all issues related to establishing, developing and managing the business. The business plan is a source of knowledge about the potential dormant in a business project, and it also points out the opportunities and threats that result from the present and future situation in the market in which the organization is located.

The business plan developed for the "Cicha Przystań" elderly care home has shown all the strengths and weaknesses of this undertaking and its threat potential. An in-depth analysis has made it possible to identify competition in the market and the need for services provided by such care facilities, thereby improving the quality of the elderly life. A perfect location and developed offer will make the company appear on the market. Calculations in the financial plan have shown that the project can be profitable in the future.
\end{abstract}

KEYWORDS: business plan, nursing home, quality of life, elderly.

nocześnie o swoje zdrowie oraz rozwój zainteresowań, na które w przeszłości nie mieli czasu. Patrząc przez pryzmat nieustannego zwiększania się odsetka ludzi w podeszłym wieku w społeczeństwie można stwierdzić, iż powoli zanika także tradycja rodzin wielopokoleniowych, przez co wzrasta zainteresowanie ośrodkami opieki, które zapewniłyby osobom starszym skoordynowaną oraz całodobową opiekę [1].

Aby prowadzić w efektywny sposób działalność, w tym także działalność leczniczą, nie wystarczy „po- 
mysł na biznes", ale także należy mieć na uwadze skuteczny plan jego wdrożenia. W tym może pomóc opracowanie biznesplanu, który poprzez sprecyzowanie oraz zdefiniowanie pomysłu prowadzi do spełnienia założonego celu. Jest on skuteczną metodą sprawdzenia planowanej inwestycji [2].

Takie narzędzie jak biznesplan staje się przewodnikiem każdego przedsiębiorcy rozpoczynającego swoją działalność, bowiem umożliwia odpowiednio przewidzieć zamierzone działania, eliminując ryzyko niepowodzenia. Jako dokument planistyczny umożliwia szeroką analizę wszystkich zagadnień obejmujących daną działalność, dlatego też zawiera najlepsze sposoby na rozwiązanie pojawiających się problemów i trudności [3].

Uwzględniając analizę rynku oraz nieustanny wzrost demograficzny osób w wieku senioralnym, którym należy zapewnić kompleksowe i odpowiadające im warunki do dalszej egzystencji, zasadne staje się opracowanie biznesplanu domu opieki nad osobami starszymi.

\section{Poprawa jakości życia osób w podeszłym wieku poprzez opracowanie biznesplanu domu opieki nad osobami starszymi}

Konstruując biznesplan, należy w pierwszej kolejności przedstawić ogólną charakterystykę przedsięwzięcia, profil oraz misję, wizję i cel działalności. Przeważnie w ogólnym opisie zamieszcza się pełną nazwę zakładu, formę organizacyjno-prawną oraz dane osobowe właścicieli. Niekiedy lokuje się tu także historię przedsiębiorstwa, lecz ma to miejsce, gdy dana organizacja już funkcjonuje na rynku od jakiegoś czasu [4].

Dom opieki nad osobami starszymi „Spokojna Przystań” jest jednoosobową prywatną działalnością gospodarczą, której przewidywany termin rozpoczęcia wyznaczony jest na wrzesień 2017 roku.

Placówka nastawiona jest na świadczenie usług opiekuńczych, w tym pomocy w wykonywaniu podstawowych czynności życiowych oraz zapewnienie opieki medycznej osobom w podeszłym wieku, które są przewlekle chore i niepełnosprawne. Przewidywana liczba miejsc w domu opieki wynosi 30, lecz w dalszej perspektywie planuje się rozszerzyć działalność i zwiększyć liczbę miejsc stacjonarnych. Natomiast nie ma limitów, jeśli chodzi o klientów z zewnątrz.

Siedziba firmy znajduje się nieopodal Rezerwatu Przyrody Żurawiniec. Wybór takiej lokalizacji umotywowany jest badaniami rynku, z których wyraźnie wynika, iż w społeczeństwie nastąpił wzrost liczebny osób starszych, które potrzebują wyciszenia i spokoju z dala od miejskiego zgiełku na okres późniejszych lat swojego życia.

Do zakresu świadczeń realizowanych przez dom opieki „Spokojna Przystań” będą należały m.in.:

- usługi bytowe,
- usługi opiekuńcze,

- usługi medyczne,

- usługi turystyczno-rekreacyjne,

- $\quad$ zabiegi rehabilitacyjne i fizjoterapeutyczne (dostępne dla osób z zewnątrz w systemie ambulatoryjnym).

Misja działalności opisuje cel, dla którego została ona uruchomiona, oraz precyzuje funkcję, jaką organizacja ma do spełnienia w danym środowisku. Powinna odnosić się do przyszłości, zawierając pomysły i wyzwania kierownictwa oraz pracowników w celu spełnienia zaplanowanego biznesu [5].

Misja domu opieki „Spokojna Przystań” brzmi: „Zapewnienie odpowiedniej i komfortowej opieki nad osobami starszymi przez całą dobę. Priorytetem jest pomoc ludziom starszym, aby w spokoju i szczęściu cieszyli się życiem".

Wizja firmy stanowi koncepcję jej przyszłości, gdyż przedsiębiorca zakładając działalność musi wiedzieć, co chce osiągnąć i do czego dąży [6].

Wizja domu opieki nad osobami starszymi „Spokojna Przystań” prezentuje się następująco: „Ośrodek mieści się w pobliżu Rezerwatu Przyrody Żurawiniec. Bogata oferta usług obejmuje świadczenia z zakresu codziennej pielęgnacji, rehabilitacji i fizjoterapii dla podopiecznych domu oraz osób z zewnątrz. Ponadto ośrodek świadczy usługi turystyczno-rekreacyjne oraz zapewnia całodobową opiekę lekarską i stałe monitorowanie stanu zdrowia podopiecznych. Utrzymanie wysokiej jakości świadczeń jest możliwe dzięki uzyskaniu dofinansowań z różnych instytucji, np. UE”.

Cele stanowią pożądany, przyszły stan, do którego dąży dana działalność [7].

Podstawowym celem działalności domu opieki nad osobami starszymi określono następująco: „Zapewnienie odpowiedniej opieki nad osobami starszymi przez całą dobę. Chcemy stworzyć przyjazną atmosferę dla ludzi, którzy potrzebują pomocy oraz zapewnić im godne warunki mieszkaniowe".

Kolejną niezbędną częścią biznesplanu jest plan organizacyjny, który określa właściwe funkcjonowanie każdej firmy poprzez określenie organizacji pracy oraz posiadanych zasobów.

Działalność musi wybrać dla siebie odpowiednią strukturę organizacyjną, bowiem dzięki temu można poznać zależności między danymi stanowiskami oraz sprawnie i efektywnie zarządzać organizacją. Rodzajów struktur organizacyjnych jest wiele, jednak autor biznesplanu wybrał strukturę liniową, gdzie hierarchia między komórkami jest od razu widoczna - personel podlega dyrektorowi zarządzającemu całą działalnością. Ten rodzaj struktury umożliwia precyzyjne określenie zadań i odpowiedzialności za nie konkretnym członkom organizacji [8]. 
Struktura projektowanej organizacji została zaprezentowana na rycinie $\mathbf{1 .}$

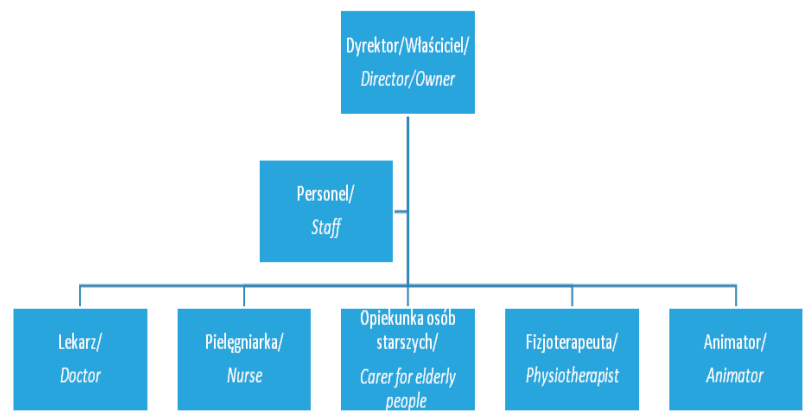

Rycina 1. Struktura organizacyjna domu opieki nad osobami starszymi „Spokojna Przystań”

Rycine 1. The organizational structure of the old people's home 'Spokojna Przystań'

Źródło: opracowanie własne.

Source: author's own analysis.

Ważną kwestią jest odpowiednie zaplanowanie działań i harmonogramu ich realizacji, by uruchomić działalność. Przy planowaniu działań niezbędne jest podanie wykonawcy oraz osoby, która będzie nadzorowała cały proces. Przykład, jak powinien wyglądać harmonogram działań w celu uruchomienia działalności, przedstawia tabela 1.

Tabela 1. Harmonogram działań w celu uruchomienia działalności Table 1. Activities schedule to set up a business

\begin{tabular}{|c|c|c|c|c|c|}
\hline $\begin{array}{c}\text { Oznaczenie/ } \\
\text { Symbol }\end{array}$ & $\begin{array}{c}\text { Działanie/ } \\
\text { Activity }\end{array}$ & $\begin{array}{c}\text { Początek/ } \\
\text { Start }\end{array}$ & $\begin{array}{l}\text { Koniec/ } \\
\text { Finish }\end{array}$ & $\begin{array}{c}\text { Wykonawca/ } \\
\text { Performer }\end{array}$ & $\begin{array}{c}\text { Nadzorowa- } \\
\text { nie/ } \\
\text { Supervision }\end{array}$ \\
\hline$A$ & $\begin{array}{l}\text { Złożenie bizne- } \\
\text { splanu } \\
\text { w banku/ } \\
\text { Submitting the } \\
\text { business plan } \\
\text { to the bank }\end{array}$ & $\begin{array}{l}\text { 02-01- } \\
2017 r .\end{array}$ & $\begin{array}{l}\text { 02-01- } \\
2017 r .\end{array}$ & $\begin{array}{c}\text { Daria } \\
\text { Nowadzka }\end{array}$ & $\begin{array}{c}\text { Daria } \\
\text { Nowadzka }\end{array}$ \\
\hline
\end{tabular}

Źródło: opracowanie własne.

Source: author's own analysis.

Przykładowe produkty i usługi potrzebne do realizacji działalności oraz ich dostawców przedstawiono w tabeli 2.

Tabela 2. Produkty i usługi oraz ich dostawcy Table 2. Products and services and their suppliers

\begin{tabular}{cc}
\hline Produkty i usługi/ & Dostawca/ \\
Products and services & Supplier \\
\hline Energia/Energy & Energa \\
Gaz/Gas & PGNiG \\
Hurtownia/Warehouse & Superpharm \\
\hline
\end{tabular}

Źródło: opracowanie własne.

Source: author's own analysis.

Założono, że niektóre prace, takie jak sprzątanie, prace ogrodnicze, ochrona mienia i wyżywienie pod- opiecznych mogą być realizowane w ramach usług outsourcingowych.

Kolejnym krokiem jest analiza rynku, w którym znajdują się informacje o potencjalnych odbiorcach oferowanych świadczeń. Jak wiemy, w Polsce z roku na rok liczba osób starszych rośnie, przy czym często towarzyszy im ograniczenie sprawności oraz potrzeba opieki nad nimi przez osoby z zewnątrz. Analizując powyższe można dojść do wniosku, iż niezbędne staje się zapewnienie osobom starszym skoordynowanej oraz całościowej opieki senioralnej [1].

Jak wynika z raportu dotyczącego udziału seniorów w życiu publicznym województwa wielkopolskiego, najdłużej żyje się w samym Poznaniu. Pod koniec 2011 roku obliczono, że ludności powyżej 60 roku życia w województwie wielkopolskim było 652 tysiące, przy czym podano prognozy, iż z roku na rok będzie kształtowała się tu tendencja wzrostowa [9].

Planowana działalność w przyszłości ma być nastawiona na klientów zewnętrznych, w tym na osoby niepełnosprawne, a z danych zaczerpniętych z Narodowego Spisu Powszechnego z 2011 r. wynika, że liczba gospodarstw domowych z osobami z niepełnosprawnością w województwie wielkopolskim wynosiła 338843, co stanowi 30\% wszystkich gospodarstw domowych [10].

Analizując rynek, należy zapoznać się z istniejącą na nim konkurencją. Rozwój wszystkich działalności uzależniony jest od sposobu działania rynku. Należy pamiętać, iż elastyczność i otwartość na zmiany gwarantuje pełen sukces, bowiem sektor ciągle ulega wpływom klientów, którzy mają coraz większe wymagania i potrzeby, przez co by ich pozyskać należy wdrażać nieustanne zmiany. Świadczeniobiorca ma swobodę wyboru placówki usługowej, dlatego też pojawia się coraz większa konkurencja na rynku, która stymuluje wszystkie zakłady lecznicze do poprawy jakości świadczonych usług [11].

Największym atutem, który decyduje o wyborze ośrodka, jest kameralność placówki, w której mieszka niewielka liczba osób. Ponadto liczy się zapewnienie poczucia bezpieczeństwa oraz pomocy całodobowej dla osoby, której będzie to niezbędnie potrzebne.

Dane wojewody wielkopolskiego informują, iż w województwie znajduje się ponad 20 prywatnych domów opieki nad osobami starszymi [12]. W Wielkopolsce istnieją ponadto domy opieki społecznej, które mogą stanowić organizację zastępczą dla prywatnych działalności, lecz do każdego takiego ośrodka jest bardzo długa lista chętnych i oczekujących.

Wielkopolski Urząd Wojewódzki w Poznaniu, szczególnie Wydział Polityki Społecznej i Zdrowia prowadzi rejestr Domów Pomocy Społecznej, z którego 
wynika, iż domów pomocy społecznej na terenie województwa jest 66, a w samym Poznaniu 7, z których typowo 3 są ośrodkami dla osób w podeszłym wieku i dysponują 311 miejscami (stan na styczeń 2016 r.). Ponadto urząd prowadzi rejestr placówek zapewniających całodobową opiekę osobom niepełnosprawnym, przewlekle chorym lub w podeszłym wieku, w tym prowadzonych na podstawie przepisów o działalności gospodarczej, których na terenie województwa jest 29. Znajduje się w nich ponad 700 miejsc dla osób starszych. Należy zaznaczyć, iż liczba prywatnych placówek stale wzrasta, gdyż społeczeństwo się starzeje, a potrzeby z każdym rokiem rosną (aktualizacja 17 marca 2016 r.) [13].

Większość prywatnych placówek na terenie powiatu poznańskiego oferuje swoim podopiecznym dobre warunki mieszkaniowe, zapewniając im bezpieczeństwo i profesjonalną opiekę. Mimo licznej konkurencji autorka ma nadzieję, że proponowane przez nią przedsięwzięcie będzie na tyle atrakcyjne, że przyciągnie grono osób chętnych do zamieszkania właśnie w tym ośrodku. Jak powszechnie wiadomo, konkurencja jest czynnikiem bardzo potrzebnym do rozwoju organizacji, bowiem dzięki niej poprawia się jakość świadczonych usług a także satysfakcja pacjentów czy też klientów danej placówki.

Bardzo często organizacje, tworząc biznesplan, opierają określenie pozycji na rynku na analizie SWOT. Poprzez taką rzetelną analizę można określić wszystkie silne i słabe strony przedsięwzięcia oraz jego możliwości i zagrożenia, które mogą pojawić się w otoczeniu.

Niektóre mocne i słabe strony oraz szanse i zagrożenia dla domu opieki „Spokojna Przystań” zostały zaprezentowane w tabeli 3.

Tabela 3. Niektóre mocne i słabe strony oraz szanse i zagrożenia dla domu opieki „Spokojna Przystan”

Table 3. Some of the strengths, weaknesses, opportunities and threats for the old people's home 'Spokojna Przystań'

\begin{tabular}{|c|c|c|c|}
\hline $\begin{array}{l}\text { Mocne strony/ } \\
\text { Strengths }\end{array}$ & $\begin{array}{l}\text { Słabe strony/ } \\
\text { Weaknesses }\end{array}$ & $\begin{array}{c}\text { Szanse/ } \\
\text { Opportunities }\end{array}$ & $\begin{array}{l}\text { Zagrożenia/ } \\
\text { Threats }\end{array}$ \\
\hline $\begin{array}{c}\text { Szeroki profil } \\
\text { oferowanych } \\
\text { usług/ } \\
\text { The wide profile } \\
\text { of services } \\
\text { offered }\end{array}$ & $\begin{array}{c}\text { Firma rozpoczyna } \\
\text { dopiero swoją } \\
\text { działalnośćl } \\
\text { The company has } \\
\text { just started its } \\
\text { activity }\end{array}$ & $\begin{array}{l}\text { Duże zapotrzebo- } \\
\text { wanie na opiekę } \\
\text { nad osobami } \\
\text { starszymi, wyni- } \\
\text { kające ze zjawi- } \\
\text { ska starzenia się } \\
\text { społeczeństwa/ } \\
\text { The high demand } \\
\text { for care for the } \\
\text { elderly people, } \\
\text { resulting from the } \\
\text { phenomenon of } \\
\text { an aging society }\end{array}$ & $\begin{array}{l}\text { Brak zaufania do pry- } \\
\text { watnego domu opieki } \\
\text { ze strony potencjalnych } \\
\text { klientów, pacjentów/ } \\
\text { Lack of trust to } \\
\text { a private care home } \\
\text { from potential clients, } \\
\text { patients }\end{array}$ \\
\hline
\end{tabular}

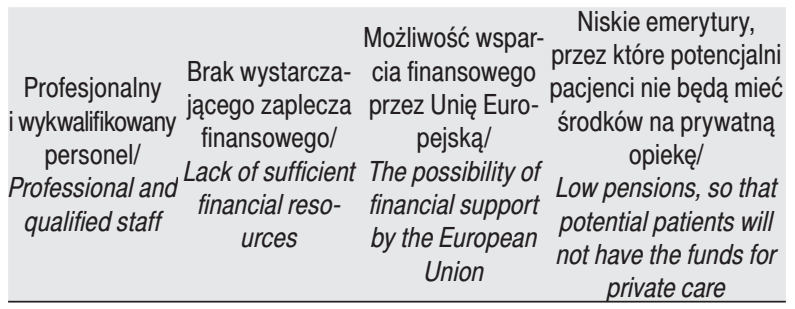

Źródło: opracowanie własne.

Source: author's own analysis.

Po opracowaniu analizy SWOT należy przeprowadzić wnikliwe rozpoznanie sytuacji i określić prognozy dla przyszłości placówki. Dzięki temu kierownik otrzymuje niezbędną wiedzę o możliwościach spożytkowania silnych stron i szans organizacji, przy równoczesnym niwelowaniu słabości oraz zwalczaniu zagrożeń [14].

W biznesplanie powinno także znaleźć się miejsce dla analizy strategicznej, która pozwala określić kolejno następujące po sobie etapy wdrażania działań, by skutecznie realizować cele organizacji. Analizując informacje, które znajdują się w biznesplanie domu opieki dla osób starszych „Spokojna Przystań”, można ustalić etapy wprowadzania strategii działalności. Oto niektóre z nich:

- zakup niezbędnego sprzętu i urządzeń potrzebnych do świadczenia usług podopiecznym do dnia 31-05-2017 r.

- reklamowanie oferty placówki na portalach internetowych oraz $\mathrm{w}$ lokalnej prasie: od dnia 15-06-2017 r. do 15-09-2017 r.

- oficjalne otwarcie domu opieki nad osobami starszymi „Spokojna Przystań” w dniu 15-09-2017 r.

W okresie kolejnych 3 lat właściciel będzie dążył między innymi do:

- rozszerzenia oferty dla osób spoza domu opieki, co przyczyni się do zwiększenia zysku o 20\%: od dnia 16-09-2017 r.

- zatrudnienia dodatkowego personelu: do dnia 15-11-2018 r.

- rozbudowy placówki: od dnia 30-04-2019 r. do 15-08-2019 r.

Działania, które są nastawione na marketing, muszą być także uwzględnione w biznesplanie. Celem dobrze opracowanego planu marketingowego jest wzrost efektywności przedsięwzięcia, czyli uzyskanie jak największych zysków z działalności poprzez pozyskanie i utrzymanie klientów-pacjentów.

Strategię marketingową domu opieki nad osobami starszymi „Spokojna Przystań” najlepiej przedstawiają elementy składowe Marketingu-Mix, czyli produkt/usługa, cena, dystrybucja oraz promocja. 


\section{Produkt/usługa}

- Zakład opieki prowadzi dokładną analizę wszystkich świadczonych usług, dzięki czemu ma orientację, jakie usługi są niezbędne w ofercie. Wykorzystując badania marketingowe można stwierdzić, iżobserwuje się nieustannezapotrzebowanie na świadczenie usług całodobowych w zakresie zapewnienia bytu podopiecznych domu opieki, usług opiekuńczych, usług medycznych, w tym rehabilitacji i fizjoterapii, a także zagwarantowania organizacji czasu wolnego poprzez usługi turystyczno-rekreacyjne dla osób w podeszłym wieku. Ponadto ośrodek oferuje usługi z zakresu zabiegów rehabilitacyjnych oraz fizjoterapii dla zainteresowanych osób z zewnątrz.

\section{Cena}

- $\quad$ Poziom cen usług uzależniony jest od cen konkurencji świadczącej podobne usługi na rynku poznańskim, jak i w mniejszej mierze od wynagrodzeń pracowników świadczących konkretne zabiegi.

- Dla podopiecznych domu opieki, którzy będą mieć zapewnioną całodobową opiekę, przewidziana jest stała opłata miesięczna za wyżywienie, przy czym koszt miesięcznego pobytu rozliczany będzie według stawek jednostkowych za poszczególne usługi, które będą świadczone danemu podopiecznemu.

- Ponadto istnieje możliwość zakupu usługi przez klientów z zewnątrz, która będzie rozliczana według cennika dla klientów zewnętrznych. Usługa: rehabilitacja, fizjoterapia, zajęcia aktywizujące, a także wyjścia organizowane przez ośrodek, których ceny będą podawane podczas organizacji wyprawy, ze względu na zależność cen od rodzaju wyjazdu oraz formy wycieczki.

- Bezpłatnie dla wszystkich podopiecznych raz dziennie będą wykonywane pomiary ciśnienia oraz pomiar poziomu cukru, w celu zapewnienia kompleksowego świadczenia usług pacjentom ośrodka.

3. Dystrybucja

- Dom opieki nad osobami starszymi będzie jednym z nielicznych ośrodków prywatnych na terenie województwa wielkopolskiego, w którym zapotrzebowanie na usługi związane z całodobową opieką nad osobą w podeszłym wieku oraz na zabiegi z zakresu fizjoterapii i rehabilitacji ciągle wzrasta. W miarę upływu czasu oferowane przez zakład opieki usługi będą poszerzane w oparciu o potrzeby pacjentów odwiedzających placówkę. Usługi będą świadczone na terenie ośrodka, w zamierzeniach przyszłościowych przewiduje się poszerzenie oferty o dojazd do domu klienta.

\section{Promocja}

- $\quad$ Dom opieki przez 3 najbliższe lata będzie prowadził bardzo aktywną kampanię promocyjną, gdyż zamierzeniem jest wykreowanie w jak najszybszym czasie pozytywnego wizerunku placówki oraz usług, jakie oferuje, a także dotarcie do jak największego grona potencjalnych odbiorców.

- Działalność będzie reklamowana i promowana m.in. za pomocą:

- strony internetowej, na której będzie przedstawiona oferta działalności, adres oraz kontakt do ośrodka, a także cennik usług,

- ogłoszeń w prasie lokalnej,

- marketingu szeptanego,

- plakatów oraz drogowskazów prowadzących do domu opieki.

- Wszelkie koszty reklamy i promocji będą pokryte początkowo z kapitału, którym dysponuje właściciel przedsięwzięcia, a następnie z zysku wypracowanego na działalności.

- Wszystkie działania marketingowe będą stale monitorowane, by sprawdzić, czy przynoszą zaplanowany efekt. W przypadku odchyleń od zakładanych wyników działania marketingowe będą musiały być poprawione lub też zastąpione innymi formami promocji i reklamy.

W biznesplanie ważnym elementem jest plan finansowy, dzięki któremu można określić przewidywane koszty oraz przychody z zamierzonej działalności, by racjonalnie podjąć decyzję co do opłacalności przedsięwzięcia oraz dokonać oceny ryzyka.

Udział kapitału zaangażowanego w działalność domu opieki nad osobami starszymi „Spokojna Przystań” zawiera się w kapitale własnym, kapitale obcym oraz dodatkowych środkach uzyskanych z dofinansowań.

Rozpoczynając działalność, trzeba liczyć się z kosztami początkowymi, które są nieuniknione, lecz wraz z rozwojem działalności stają się znikome.

Koszty początkowe wynikające z założenia opisywanego podmiotu leczniczego, które zostaną sfinansowane z kapitału własnego, przedstawia tabela 4.

Tabela 4. Koszty początkowe działalności finansowane środkami własnymi Table 4. Costs of initial activities financed with own funds

\begin{tabular}{c} 
Rodzaj działania/The type of action \\
\hline Założenie działalności/Setting up a business \\
Reklama/Advertisement \\
Wyposażenie ośrodka/Equipment of care home \\
Sprzęty fizjoterapeutyczne i rehabilitacyjne/Physiotherapy and rehabilitation \\
equipment \\
SUMA/ Amount $=48500$ PLN
\end{tabular}

Źródło: opracowanie własne.

Source: author's own analysis. 
Planowane wydatki domu opieki nad osobami starszymi ze środków obcych ukazuje tabela 5.

Tabela 5. Planowane wydatki na rozpoczęcie działalności zakładu opieki „Spokojna Przystań”

Table 5. The planned expenditure for setting up the old people's home "Spokojna Przystań"

Przeznaczenie - rodzaj zakupu/Purpose - type of purchase

Remont oraz adaptacja ośrodka/Renovation and adaptation of care home Sprzęty fizjoterapeutyczne i rehabilitacyjne/Physiotherapy and rehabilitation equipment

Działania marketingowe/Marketing activities

Budowa zaplecza sportowo-rekreacyjnego/Building of recreational facilities SUMA $/$ Amount $=518000 \mathrm{PLN}$

Źródło: opracowanie własne.

Source: author's own analysis.

Ponadto do wyżej wymienionych wydatków należy także doliczyć koszty zasobów ludzkich, koszty usług outsourcingowych, a także koszty środków pielęgnacyjno-medycznych. Dodatkowo należy wziąć pod uwagę miesięczne koszty usługi księgowej oraz ubezpieczenia obiektu. Wymienione koszty będą naliczane po rozpoczęciu działalności.

Głównym założeniem opracowania planu finansowego powinno być nastawienie na wypracowanie zysku, po odliczeniu od przychodów kosztów działalności. Należy pamiętać, iż wypracowany zysk będzie musiał po części być przeznaczony na spłatę kredytu, który został zaciągnięty przez właściciela na okres 20 lat.

Rozpatrując założenia finansowe, należy zwrócić uwagę na kwestię liczby świadczonych usług, w perspektywie opłacalności.

Liczbę usług świadczonych podopiecznym przedstawia tabela 6.

Tabela 6. Liczba świadczonych usług

Table 6. Number of services

\begin{tabular}{|c|c|c|c|}
\hline $\begin{array}{l}\text { Usługa/ } \\
\text { Service }\end{array}$ & $\begin{array}{l}\text { Dziennie/ } \\
\text { Daily }\end{array}$ & $\begin{array}{l}\text { Tygodniowo/ } \\
\text { Weekly }\end{array}$ & $\begin{array}{c}\text { Miesięcznie/ } \\
\text { Monthly }\end{array}$ \\
\hline $\begin{array}{c}\text { Pomiar ciśnienia/ } \\
\text { Pressure measurement }\end{array}$ & $\begin{array}{c}70 \text { (w zależności od } \\
\text { potrzeb)/ } \\
70 \text { (depending on the } \\
\text { needs) }\end{array}$ & 490 & 2100 \\
\hline $\begin{array}{l}\text { Pomiar poziomu cukru/ } \\
\text { Measuring the level of } \\
\text { sugar }\end{array}$ & (lee(us) & 168 & 720 \\
\hline $\begin{array}{l}\text { Rehabilitacja i fizjoterapia/ } \\
\text { Rehabilitation and physio- } \\
\text { therapy }\end{array}$ & $\begin{array}{c}30 \text { (45 minut)/30 (45 } \\
\text { minutes) }\end{array}$ & 210 & 900 \\
\hline $\begin{array}{l}\text { Pielęgnacja/ } \\
\text { Care }\end{array}$ & $\begin{array}{c}60 \text { (w zależności od } \\
\text { potrzeb)/ } \\
60 \text { (depending on the } \\
\text { needs) }\end{array}$ & 420 & 1800 \\
\hline $\begin{array}{c}\text { Zajęcia aktywizujące/ } \\
\text { Activities }\end{array}$ & $\begin{array}{c}2 \text { (1 godzina)/ } \\
\text { (1 hour) }\end{array}$ & 14 & 60 \\
\hline $\begin{array}{c}\text { Wyjścia/ } \\
\text { Exits }\end{array}$ & 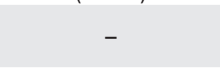 & 2 & 8 \\
\hline $\begin{array}{c}\text { Rehabilitacja - klienci } \\
\text { zewnętrzni/ } \\
\text { Rehabilitation-extemal clients }\end{array}$ & $\begin{array}{c}30 \text { (45 minut)/ } \\
30 \text { (45 minutes) }\end{array}$ & 210 & 900 \\
\hline
\end{tabular}

Źródło: opracowanie własne.

Source: author's own analysis.
Wartość świadczonych usług może ulec zmianie ze względu na to, iż ośrodek jest czynny całodobowo dla pensjonariuszy.

Przechodząc do analizy finansowej, należy dokładnie obliczyć koszty oraz przychody wynikające z funkcjonowania działalności.

Koszty usług zostały wyliczone poprzez zsumowanie kosztów wynagrodzenia, narzutu na wynagrodzenie, kosztów materiałów oraz energii, podatków i opłat oraz innych kosztów, które są potrzebne do wytworzenia usługi.

Koszty jednostkowe wynoszą od 15,00 zł do 42,00 zł (w zależności od świadczenia), w przedstawionej tabeli koszty jednostkowe łącznie wynoszą 186,00 zł, przy czym koszt miesięczny wszystkich usług kształtuje się na poziomie 181608,00 zł, co rocznie daje kwotę 2179 296,00 zł.

Aby sprawdzić, czy przedsięwzięcie będzie opłacalne, musimy wziąć pod uwagę także rachunek przychodów.

Przychody ze świadczonych usług jednostkowych wynoszą od 20,00 zł do 52,00 zł (w zależności od świadczenia). Przychody wszystkich z pojedynczych świadczeń łącznie wynoszą 277,00 zł, natomiast miesięczny przychód ze wszystkich usług wynosi 222 900,00 zł, co rocznie daje kwotę 2674 800,00 zł.

Obliczając przychody, należy także pamiętać o uwzględnieniu przychodu z wyżywienia miesięcznego osoby starszej.

Jako podsumowanie warto przedstawić przewidywany rachunek przychodów i kosztów, by sprawdzić opłacalność przedsięwzięcia. Elementy składowe rachunku przychodów i kosztów uwzględniono w tabeli 7.

Tabela 7. Elementy składowe rachunku dochodów i kosztów Table 7. Components of the income and expenditure

\begin{tabular}{l} 
Wyszczególnienie/Specification \\
\hline Przychody ze sprzedaży usług/Cash revenue on service sales \\
Koszty działalności/Activity costs \\
Zysk brutto/Gross profit \\
Podatek (18\%)/Tax \\
Zysk netto/Net profit \\
liabilities (credit) * euro \\
Spłata innych zobowiązań (kredyt) *kurs euro $=4,29$ zł/Repayment of other \\
Źródło: opracowanie własne. \\
Source: author's own analysis.
\end{tabular}

Po dokonaniu obliczeń ostateczny miesięczny zysk z działalności w rachunku dochodów i kosztów kształtuje się na poziomie 30 038,44 zł, natomiast zysk ostateczny wynosi 360 461,28 zł.

Wszystkie wyliczenia uwzględnione w planie finansowym są oparte na założeniu, że w domu opieki przebywać będzie komplet osób, a dom będzie się cieszył średnim zainteresowaniem klientów z zewnątrz. 
Istotne jest także zaplanowanie inwestycji na kolejne lata działalności. W tym przypadku inwestycje finansowe będą opierały się na poszerzeniu zakresu świadczonych usług, poprzez zakup dodatkowego sprzętu medycznego. W planach zawarto także rozbudowę placówki oraz zatrudnienie dodatkowego personelu, by świadczenia udzielane zainteresowanym osobom były na jak najwyższym poziomie.

\section{Podsumowanie}

Biznesplan składa się z najważniejszych informacji, które dotyczą danego projektu oraz zawiera wszystkie kwestie związane z zakładaniem, zarządzaniem oraz rozwojem działalności. Biznesplan jest źródłem wiedzy o potencjale drzemiącym w projekcie działalności, a ponadto wskazuje szanse i zagrożenia, które wynikają z teraźniejszej oraz przyszłej sytuacji na rynku, w którym znajduje się organizacja.

Biznesplan, który został opracowany dla domu opieki nad osobami starszymi „Spokojna Przystań” ukazał wszystkie mocne i słabe strony tego przedsięwzięcia oraz jego szanse i zagrożenia. Wnikliwa analiza pozwoliła określić konkurencję na rynku oraz fakt istnienia zapotrzebowania na usługi świadczone przez dom opieki. Z powyższego wynika, iż poprzez opracowanie biznesplanu domu opieki nad osobami starszymi możliwa jest poprawa jakości życia osób w podeszłym wieku.

\section{Piśmiennictwo}

1. Kanownik G. Żyła złota powyżej siedemdziesiątki. Menedżer Zdrowia. 2014; 9: 49.

2. Tokarski A, Tokarski M, Wójcik J. Jak solidnie przygotować profesjonalny biznesplan. Warszawa: CeDeWu; 2007. 33-34.

3. Głowacka MD, Nowomiejski J, Rasińska R, Padurek A. Biznesplan wybranego podmiotu wykonującego działalność leczniczą. W: Głowacka MD, Zdanowska J (red.). Zdrowie publiczne. Aktualne uwarunkowania i zmiany. Poznań: Polskie Towarzystwo Nauk o Zdrowiu; 2011. 135.

4. Skrzypek JT. Biznesplan. Model najlepszych praktyk. Warszawa: Poltext; 2009. 30-32.
5. Marek S, Białasiewicz M. Podstawy nauki o organizacji. Przedsiębiorstwo jako organizacja gospodarcza. Warszawa: Polskie Wydawnictwo Ekonomiczne; 2008. 40-41.

6. Obłój K. Strategia organizacji W poszukiwaniu trwałej przewagi konkurencyjnej. Warszawa: Polskie Wydawnictwo Ekonomiczne; 2007. 22-23.

7. Muhlemann A.P, Oakland J, Lockyer K.G. Zarządzanie produkcja i usługi. Warszawa: PWN; 1995. 32-33.

8. Chudy S, Kabat F, Pietraszewski M. Ekonomika i organizacja przedsiębiorstw dla specjalności finanse i rachunkowość Część 1 Podręcznik z ćwiczeniami, wydanie 5. Poznań: Wyd eMPi'; 2000. 49-50.

9. http://www.wrzos.org.pl/download/RAPORT_woj.wielkopolskie.pdf, (data dostępu 29.11.2016r.).

10. http://stat.gov.pl/spisy-powszechne/nsp-2011/nsp-2011wyniki/ (data dostępu 29.11.2016r.).

11. Kanownik G. Jak tlenu potrzebujemy konkurencji. Menedżer Zdrowia. 2015; 1: 32-35.

12. Karwowska A, Pochrzęst-Motyczyńska A, Domy spokojnej starości. Cena, oferta, jak wybrać najlepszy http://wyborcza.pl/TylkoZdrowie/1,137474,19052987, prywatne-domyopieki-co-oferuja-i-ile-to-kosztuje.html , dostęp: (data dostępu 29.11.2016r.).

13. http://www.poznan.uw.gov.pl/rejestry-ewidencje-i-archiwa/wydzial-polityki-spolecznej-i-zdrowia, (data dostępu 29.11.2016 r.).

14. Koźmiński AK, Piotrowski W. Zarządzanie. Teoria i praktyka, Warszawa: PWN; 2000. 139-141.

Artykuł przyjęty do redakcji: 28.11.2016

Artykuł przyjęty do publikacji: 15.12.2016

Źródło finansowania: Praca nie jest finansowana z żadnego źródła. Konflikt interesów: Autorzy deklarują brak konfliktu interesów.

\section{Adres do korespondencji:}

Daria Nowadzka

ul. Nadrzeczna 55

58-410 Marciszów

tel.: 666955769

e-mail: darianowadzka@gmail.com

studentka zdrowia publicznego

Uniwersytet Medyczny im. Karola Marcinkowskiego w Poznaniu 